\title{
Characterization and Antioxidant Activity Edible Film of Durian (Durio zibethinus) Seed Starch with the Addition of Soursop (Annona muricata L.) Leaf
}

\author{
Yuni Fatisa*, Nadya Agustin \\ Program Studi Pendidikan Kimia, Fakultas Tarbiyah dan Keguruan, Universitas islam Negeri Sultan Syarif Kasim \\ Riau \\ Email : yunifatisa@yahoo.co.id
}

\begin{abstract}
Edible film is one of the environmentally friendly packaging materials and not harmful to health because it is made up of natural ingredients such as proteins, lipids, and polysaccharides. In addition to environmentally friendly, the development of edible film on food packaging can provide better product quality, as it is made from natural ingredients that contain various natural chemical compounds that are beneficial and can be directly consumed. In this study prepared edible film derived from durian seed starch with the addition of soursop leaf extract. This research aimed at knowing the physical and chemical characteristics, and antioxidant activity of the edible film. The type of research used is experiment methods. The results showed that the best research findings of the edible film were on the addition of $2 \mathrm{~g}$ soursop leaf extract and the physical characteristic was transmission of water vapor that was $1.70 \mathrm{~g} / \mathrm{m}^{2} .24$ hours, the chemical characteristics were water content that was $17.33 \%$ and activity of antioxidant that was $1.5875 \mathrm{mg} / \mathrm{mL}$.
\end{abstract}

Keywords: Edible Film, Durian Seed Starch, Soursop Leaf Extract,Characterization, Antioxidant activity

\section{Pendahuluan}

Pemanfaatan polimer sebagai bahan kemasan untuk mempertahankan kualitas produk secara meluas telah digunakan pada produk pangan dan hasil pertanian misalnya kemasan yang terbuat dari polimer plastik, kertas, aluminium foil, logam dan kayu. Plastik menjadi kemasan yang paling populer dan sangat luas penggunaannya. Plastik yang banyak digunakan saat ini adalah jenis plastik sintetis berbahan baku naptha, yaitu bahan hasil penyulingan minyak bumi dan gas alam ${ }^{1}$. Plastik sintetis memiliki beberapa keunggulan yaitu sifatnya yang fleksibel, ekonomis, kuat, ringan, dan tidak mudah pecah. Namun, tanpa disadari plastik dapat mencemari bahan pangan yang dikemas karena adanya zat-zat tertentu yang berpotensi karsinogen ${ }^{2}$. Selain itu, plastik dari minyak bumi atau petrokimia yang memiliki bobot molekul besar, jumlah cincin aromatik yang tinggi, dan ikatanikatan yang kompleks membuatnya sulit terurai secara biologis oleh bakteri dan mikroba. Hal ini karena bakteri dan mikroba tidak memiliki enzim yang mampu mendegradasi polimer dari bahan minyak bumi sehingga penumpukan limbahnya dapat mencemari lingkungan ${ }^{3}$.

Seiring dengan kesadaran masyarakat dunia akan pentingnya kesehatan dan kualitas suatu produk pangan yang dikemas terutama pada sifat ketahannannya, maka mulai dikembangkan jenis kemasan ramah lingkungan yang dikenal dengan edible film. Edible film adalah lapisan tipis yang terbuat dari bahan yang dapat dikonsumsi untuk melapisi makanan dan menjadi penghambat transfer massa seperti kelembaban, oksigen, karbon dioksida, aroma serta zat-zat terlarut pada makanan dan atau sebagai pembawa aditif (antimikroba, antioksidan dan flavor) juga dapat meningkatkan karakteristik makanan. Selain ramah lingkungan, pengembangan edible film pada kemasan pangan dapat memberikan kualitas produk yang lebih baik, karena terbuat dari bahan alami yang tidak beracun dan dapat langsung dikonsumsi ${ }^{4}$. 
Bahan utama dalam pembuatan edible film adalah pati yang berasal dari tumbuh-tumbuhan, baik dari bagian batang, buah, akar, maupun umbi ${ }^{5}$. Dalam Al-Quran surat An-Nahl :11, Allah Subhanahu wa Ta'ala berfirman:

Artinya: "Dia menumbuhkan bagi kamu dengan

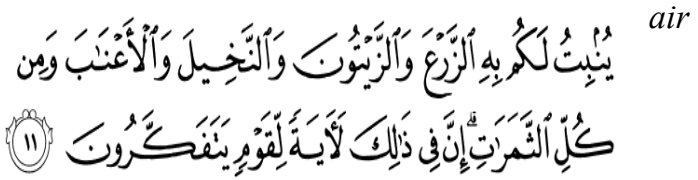

hujan itu tanam-tanaman; zaitun, korma, anggur, dan segala macam buah-buahan. Sesungguhnya pada yang demikian itu benar-benar ada tanda-tanda kekuasaan Allah bagi kaum yang memikirkan"'.

Ayat tersebut menjelaskan bahwa Allah Subhanahu Wa Ta'ala menciptakan segala yang ada di bumi seperti tanam-tanaman maupun buahbuahan agar dimanfaatkan baik untuk kelangsungan hidup maupun mengatasi masalah lingkungan. Kita sebagai makhluk ciptaan-Nya harus mensyukuri apa yang telah diberikan sebagai tanda-tanda kekuasaan-Nya.

Salah satu tanaman yang bermanfaat adalah durian. Selain buahnya yang dapat dikonsumsi, limbah biji durian yang ketersediannya melimpah dan belum dimanfaatkan secara optimal memiliki kandungan pati yang cukup tinggi sebagai bahan utama pembuatan edible film, yaitus ekitar $43,6 \%$. Penelitian sebelumnya telah menggunakan pati dari limbah biji durian sebagai bahan pembuatan plastik biodegradable pada variasi suhu $70^{\circ}, 80^{\circ}$, dan $90^{\circ} \mathrm{C}$ sehingga dihasilkan plastik biodegradable terbaik pada suhu $80^{\circ} \mathrm{C}$ dengan nilai kuat tarik sebesar $1187,32 \mathrm{~N} / \mathrm{m}^{2}$ dan \% elongasi sebesar 7,547\% ${ }^{7}$. Selain pati biji durian, bahan lain yang dapat digunakan dalam pembuatan edible film adalah pati sukun. Pada edible film dengan formulasi pati sukun-kitosan 6:4 memiliki nilai kuat tarik sebesar 16,34 $\mathrm{MPa}$, nilai elongasi sebesar 6,00\% dan modulus young sebesar $2,72 \mathrm{Mpa}^{8}$.

Selain berperan sebagai pengemas bahan makanan, edible film juga dapat berfungsi sebagai pembawa senyawa antioksidan yang mampu menghambat terjadinya oksidasi pada makanan dalam kemasan ${ }^{3}$. Salah satu sumber antioksidan yang dapat digunakan adalah daun sirsak. Daun sirsak mempunyai kandungan senyawa seperti asetogenin, saponin polifenol dan flavonoid. Flavonoid dikenal sebagai antioksidan alami. Senyawa flavonoid yang terkandung dalam daun sirsak berfungsi sebagai antioksidan yang dapat menghambat terbentuknya radikal bebas, menghambat peroksidasi lemak dan mengubah struktur membran sel. Aktifitas flavonoid ini disebabkan oleh adanya gugus hidroksi fenolik dalam struktur molekulnya juga melalui daya tangkap terhadap radikal bebas serta aktivitasnya sebagai pengkelat logam ${ }^{9}$. Berdasarkan uji aktivitas antioksidan menggunakan metode DPPH (1,1diphenyl-2-picryl hydrazil), daun sirsak memiliki nilai $\mathrm{IC}_{50}$ sebesar $70,89 \mu \mathrm{g} / \mathrm{mL}$ dan diklasifikasikan sebagai antioksidan yang kuat ${ }^{10}$. Penelitian ini bertujuan untuk mengetahui karakteristik fisik dan kimia serta sifat antioksidan edible film dari pati biji durian (Durio zibethinus) dengan penambahan ekstrak daun sirsak (Annona muricata L.).

\section{METODE PENELITIAN}

\subsection{Bahan Kimia, Peralatan dan Instrumentasi}

Alat-alat gelas, lumpang alu, hot plate stirrer, micropipette, Microplate, blender, desikator, pisau, corong saring, rotary evaporator dan spektrofotometer UV-Vis. Biji durian, daun sirsak, air kapur, etanol $96 \%$, aquades, DPPH $(1,1$ diphenyl-2-picryl hydrazil), metanol.

\subsection{Prosedur Penelitian}

Persiapan Sampel

Sampel pada penelitian ini adalah biji durian yang didapatkan dari penjual durian di Jl. H.R. Soebrantas, Panam. Daun sirsak dikumpulkan dari rumah warga di Jl. Tegal Sari, Rumbai.

Biji durian yang telah dikumpulkan kemudian dikupas untuk memisahkan kulit arinya dengan inti biji durian. Inti biji durian berwarna putih kekuningan ini dipotong dengan ketebalan 2-3 mm. Inti biji durian direndam dalam air kapur terlebih dahulu sebelum dikeringkan. Perendaman air kapur dilakukan selama 1 jam untuk mengeluarkan lendir dalam biji durian. Inti biji durian yang telah direndam, dibersihkan dengan air untuk menghilangkan lendir biji durian dan kapur yang menempel pada biji durian. Inti biji durian yang telah bersih, dikeringkan selama 2-3 hari untuk menghilangkan kadar air dalam biji durian. Inti biji durian yang telah kering ditumbuk dengan lumpang alu dan diayak dengan ayakan berukuran 140 mesh sehingga menjadi butiran halus pati biji durian ${ }^{11}$.

\section{Pembuatan Ekstrak Daun Sirsak}

Daun sirsak yang telah dikumpulkan mulamula dicuci bersih dan dipotong kecil-kecil. Kemudian daun sirsak dikeringanginkan tanpa paparan sinar matahari langsung selama 3 hari. Daun sirsak yang telah kering di blender hingga menjadi bubuk. Selanjutnya dilakukan ekstraksi dengan cara merendam bubuk simplisia daun sirsak ke dalam pelarut etanol $96 \%$ pada suhu ruang (25$27^{\circ} \mathrm{C}$ ) selama 2 hari. Kemudian sampel dimasukkan ke dalam sonikator untuk dilakukan proses sonikasi selama 30 menit. Setelah itu, dilakukan penyaringan menggunakan kertas saring 
hingga diperoleh filtrat hasil penyaringan dan dipekatkan dengan rotary evaporator ${ }^{12}$.

\section{Pembuatan Edible Film}

Pati biji durian sebanyak 2,5 g dilarutkan dengan $50 \mathrm{~mL}$ aquades ke dalam gelas beaker. Selanjutnya ditambahkan gliserol sebanyak $1 \mathrm{~mL}$. Larutan tersebut kemudian dipanaskan menggunakan hot plate stirer pada suhu $80^{\circ} \mathrm{C}$ dengan kecepatan $6 \mathrm{rpm}$. Suspensi dalam gelas beaker dipindahkan dari hot plate dan didinginkan sampai suhu ruang. Kemudian ditambahkan ekstrak daun sirsak dengan variasi ekstrak daun sirsak (0 g; $0,5 \mathrm{~g} ; 1 \mathrm{~g}$; dan $2 \mathrm{~g}$ ). Selanjutnya diaduk kembali pada hot plate stirer hingga mengental. Larutan sampel kemudian dituangkan di atas plat kaca atau cetakan. Pengeringan dilakukan dalam oven selama 17 jam pada suhu $45^{\circ} \mathrm{C}$ dan dilanjutkan pada suhu ruang selama 1 jam untuk mempermudah pelepasan $^{2}$.

\section{Analisis Transmisi Uap Air}

Edible film yang akan diuji dipotong dengan diameter $\pm 2,5 \mathrm{~cm}$. Kemudian wadah 1 diisi $15 \mathrm{~mL}$ aquades dan ditempatkan di wadah 2 yang berisi silica gel. Sebelum itu, silica gel dikeringkan pada suhu $100^{\circ} \mathrm{C}$ selama 3 jam. Lalu wadah 2 disimpan pada suhu $25^{\circ} \mathrm{C}$. Pengukuran dilakukan setelah penyimpanan pada jam ke 24 jam. Transmisi uap air dihitung dengan rumus:

$$
W V P=\frac{\Delta W}{t \times A}
$$

Dimana: $\mathrm{W}=$ perubahan berat edible film setelah 24 jam,

$$
\begin{aligned}
& \mathrm{t}=\text { waktu }(24 \mathrm{jam}) \\
& \mathrm{A}=\text { luas area permukaan film }\left(\mathrm{m}^{2}\right)
\end{aligned}
$$

\section{Analisis Kadar Air}

Sampel ditimbang sebanyak $1 \mathrm{~g}$ dalam cawan porselen yang telah diketahui beratnya. Sampel dikeringkan dalam oven pada suhu $100-105^{\circ} \mathrm{C}$ selama 3 jam. Selanjutnya sampel didinginkan dalam desikator dan ditimbang. Perhitungan kadar air berdasarkan berat basah sebagai berikut: Kadar air $=\frac{\text { Berat awal }- \text { Berat akhir }}{\text { Berat awal }} \times 100 \%$

\section{Uji Antioksidan}

Uji aktivitas antioksidan dilakukan dengan menggunakan Microplate reader two fold delution dengan metode DPPH (1,1-diphenyl-2-picryl hydrazil) pada panjang gelombang $520 \mathrm{~nm}$. Sampel sebanyak 0,1 g dilarutkan dalam $4 \mathrm{~mL} \mathrm{MeOH}$ dalam hal ini konsentrasi sampel $100 \mu \mathrm{g} / \mathrm{mL}$. Baris A dimasukkan sampel sebanyak $50 \mu \mathrm{L}$ (plate terdiri dari baris A-H masing-masing berjumlah 12 sumur). Sebanyak $50 \mu \mathrm{L} \mathrm{MeOH}$ dimasukkan pada masing-masing sumur pada baris B-F. Baris A dipipet sebanyak $50 \mu \mathrm{L}$ dan dimasukkan ke baris B. Baris B dipipet $50 \mu \mathrm{L}$ dimasukkan ke baris $\mathrm{C}$ dan dilakukan sampai baris $\mathrm{F}$, baris $\mathrm{F}$ dipipet $50 \mu \mathrm{L}$. Lalu dibuang sehingga diperoleh konsentrasi 100; $50 ; 25 ; 12,5 ; 6,25$ dan $3,125 \mu \mathrm{g} / \mathrm{mL}$. Sedangkan pada baris $\mathrm{G}-\mathrm{H}$ diisi dengan $\mathrm{MeOH} 50 \mu \mathrm{L}$.. Baris A-G ditambahkan DPPH sebanyak $80 \mu \mathrm{L}$ dengan konsentrasi $80 \mu \mathrm{g} / \mathrm{mL}$, kemudian diinkubasi selama 30 menit. Aktivitas penangkapan radikal diukur sebagai penurunan absorbansi DPPH dengan Microplate reader dan olah data. Nilai \% inhibisi dihitung dengan rumus sebagai berikut:

Dimana : $A=$ absorbansi

$$
\% \text { Hambatan }=\frac{\text { Akontrol }- \text { Assmpel }}{\text { Akontrol }}
$$

Selanjutnya nilai $\mathrm{IC}_{50}$ dihitung dengan menggunakan persamaan regresi linier sebagai berikut:

$$
\mathrm{Y}=\mathrm{aX}+\mathrm{b}
$$

\section{HASIL DAN PEMBAHASAN}

Penggunaan bahan tunggal pada edible film seperti pati masih menyisakan beberapa kekurangan diantaranya adalah sifat rapuh dan kaku. Hal ini disebabkan oleh gaya intermolekul antar partikel penyusun pati yang menyebabkan terbentuknya tekstur edible film yang mudah patah (getas). Oleh karena itu dalam pembuatan edible film dari pati biji durian ini ditambahkan gliserol sebagai plasticizer untuk menambah sifat elastisitas. Selanjutnya dilakukan proses gelatinisasi biji durian pada suhu $77-78{ }^{\circ} \mathrm{C}$. Suhu gelatinisasi adalah suhu pada saat granula pati pecah yang dapat dilakukan dengan penambahan air panas. Kemudian larutan edible film ditambahkan variasi ekstrak daun sirsak. Dalam penelitian ini dilakukan 2 perlakuan yaitu edible film pati biji durian tanpa penambahan ekstrak daun sirsak dan edible film pati biji durian dengan penambahan ekstrak daun sirsak ( $0 \mathrm{~g}$ selanjutnya disebut $\mathrm{ES}_{1} ; 0,5 \mathrm{~g}$ selanjutnya disebut $\mathrm{ES}_{2} ; 1 \mathrm{~g}$ selanjutnya disebut $\mathrm{ES}_{3} ; 2 \mathrm{~g}$ selanjutnya disebut $\mathrm{ES}_{4}$ ).

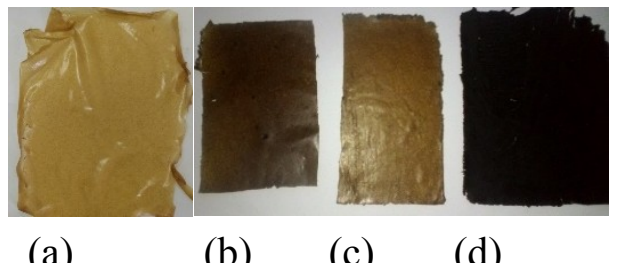
(a)
(b)
(c)
(d)

Gambar 1. Edible film dengan variasi konsentrasi ekstrak daun sirsak ((a) $\mathrm{ES}_{1}$; (b) $\mathrm{ES}_{2}$; (c) $\mathrm{ES}_{3} ;$ (d) $\mathrm{ES}_{4}$ )

Edible film yang dihasilkan tampak berbeda, untuk sampel $\mathrm{ES}_{1}$ yaitu edible film tanpa penambahan ekstrak daun sirsak berwarna coklat transparan dibandingkan dengan sampel $\mathrm{ES}_{2}, \mathrm{ES}_{3}$, dan $\mathrm{ES}_{4}$ yaitu edible film yang ditambahkan ekstrak daun sirsak 0,5 g, 1 g, dan 2 g. Semakin banyak 
ekstrak yang ditambahkan maka edible film yang dihasilkan semakin berwarna pekat sehingga tingkat kecerahan menurun. Hal ini berkaitan dengan penambahan jumlah padatan oleh ekstrak daun sirsak yang semakin besar menyebabkan ketebalan edible film semakin meningkat. Semakin tinggi nilai ketebalan edible film akan meningkatkan pembauran cahaya sehingga edible film akan nampak lebih keruh dan kecerahannya semakin rendah ${ }^{2}$.

Pada sampel $\mathrm{ES}_{3}$ yaitu edible film dengan penambahan ekstrak daun sirsak $1 \mathrm{~g}$ warna yang dihasilkan sedikit lebih terang dibandingkan sampel $\mathrm{ES}_{2}$ yaitu edible film dengan penambahan ekstrak 0,5 g karena dipengaruhi ekstrak yang kurang kental karena lamanya pengadukan. Ekstrak yang kurang kental dari daun sirsak disebabkan oleh kandungan minyak atsirinya berkurang sehingga mengakibatkan ekstrak tidak lagi mengental.

Laju transmisi uap air adalah jumlah uap air yang melalui suatu permukaan persatuan luas atau slope jumlah uap air dibagi luas area ${ }^{7}$.

Data hasil pengukuran transmisi uap air terhadap edible film dengan penambahan ekstrak daun sirsak dapat dilihat pada Tabel 1 .

Tabel 1. Hasil Pengukuran Transmisi Uap Air terhadap Edible Film.

\begin{tabular}{cc}
\hline Sampel & $\begin{array}{c}\text { Transmisi Uap Air } \\
\left(\mathbf{g} / \mathbf{m}^{\mathbf{2}} \mathbf{2 4} \text { jam }\right)\end{array}$ \\
\hline $\mathrm{ES}_{1}$ & 13,61 \\
$\mathrm{ES}_{2}$ & 8,50 \\
$\mathrm{ES}_{3}$ & 6,80 \\
$\mathrm{ES}_{4}$ & 1,70 \\
\hline
\end{tabular}

Nilai laju transmisi uap air edible film menurut standar JIS 1975 yaitu maksimal 10 $\mathrm{g} / \mathrm{m}^{2} .24 \mathrm{jam}^{13}$. Pada penelitian ini nilai transmisi uap air dari sampel $\mathrm{ES}_{2}, \mathrm{ES}_{3}$, dan $\mathrm{ES}_{4}$ memenuhi standar JIS (Japan International Standart).

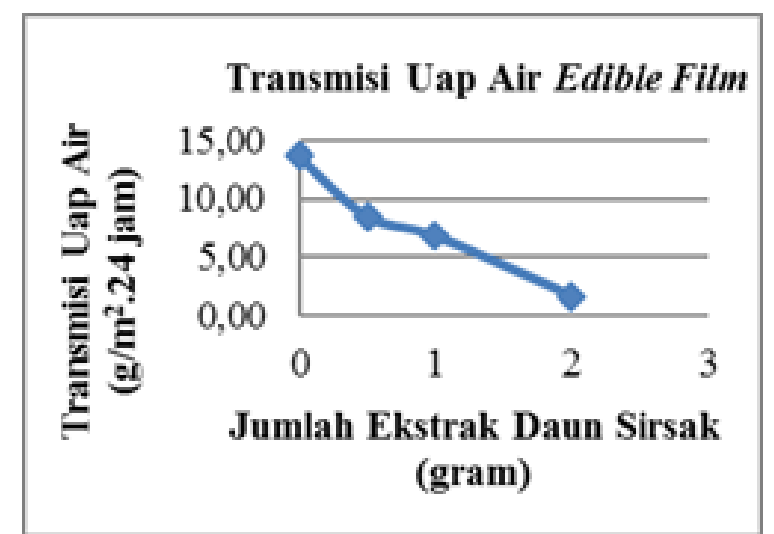

Gambar 2. Grafik Transmisi Uap Air Edible Film Akibat Pengaruh Konsentrasi Ekstrak Daun Sirsak.

Berdasarkan Gambar 2. dapat dilihat bahwa semakin tinggi kadar ekstrak daun sirsak akan menurunkan laju transmisi uap air edible film. Hal ini dikarenakan dengan meningkatnya kadar ekstrak daun sirsak maka meningkatkan total padatan ekstrak daun sirsak sehingga dapat terbentuk edible film yang tebal. Ketebalan edible film mampu mempengaruhi laju transmisi uap air karena menyebabkan laju transmisi semakin rendah seiring dengan meningkatnya ketebalannya ${ }^{14}$.

Kerapatan edible film yang tinggi akan membuat uap air sulit menembus dinding edible film tersebut dan membuat edible film tersebut memiliki nilai laju transmisi uap air yang rendah. Semakin rendah laju transmisi uap air yang melewati dinding edible film maka bahan pangan yang dikemas didalamnya akan memiliki umur simpan lebih lama ${ }^{14}$. Terlihat bahwa sampel yang memiliki transmisi uap air terbaik adalah $\mathrm{ES}_{4}$, yaitu edible film dengan penambahan ekstrak daun sirsak $2 \mathrm{~g}$ sebesar $1,70 \mathrm{~g} / \mathrm{m}^{2} .24 \mathrm{jam}$.

Kadar air sangat mempengaruhi kualitas edible film saat disimpan maupun diaplikasikan sebagai pengemas suatu produk. Pengaruh kadar air sangat penting dalam pembentukan daya awet dari bahan pangan, karena air dapat mempengaruhi sifat-sifat fisik atau adanya perubahan-perubahan kimia, serta terjadinya pembusukan oleh adanya aktivitas mikroorganisme ${ }^{15}$.

Kadar air yang tinggi rentan terhadap pertumbuhan mikroba. Respon kadar air yang dikehendaki di bawah $20 \%$ sesuai dengan persyaratan $\mathrm{SNI}^{17}$. Hasil analisis kadar air pada Gambar 3 menunjukkan bahwa sampel $\mathrm{ES}_{2}, \mathrm{ES}_{3}$, dan $\mathrm{ES}_{4}$ masih sesuai dengan persyaratan SNI.

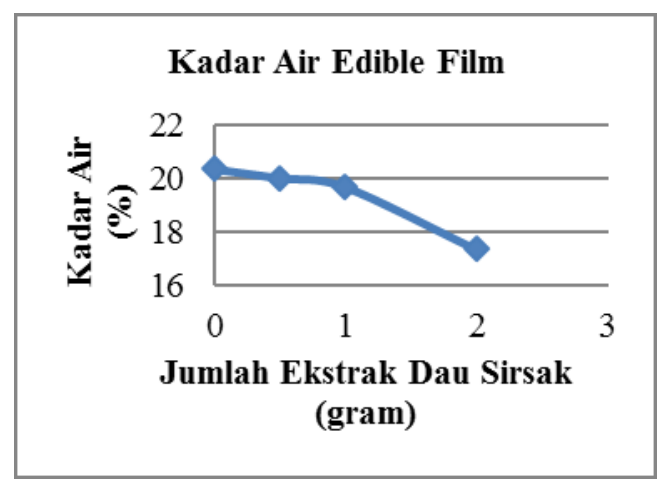

Gambar 3. Grafik Kadar Air Edible Film Akibat Pengaruh Konsentrasi Ekstrak Daun Sirsak.

Berdasarkan Gambar 3 semakin banyak ekstrak yang ditambahan pada edible film kadar air yang dihasilkan semakin menurun. Peningkatan konsentrasi ekstrak akan meningkatkan jumlah polimer dan viskositas yang menyusun matrik film. Semakin besar polimer yang menyusun matrik film 
akan meningkatkan jumlah padatan sehingga jumlah air dalam edible film semakin rendah. Hal tersebut didukung oleh pernyataan semakin besar polimer yang menyusun matrik film menyebabkan jumlah air yang tertinggal dalam jaringan film semakin rendah dan dengan bertambahnya viskositas akan berpengaruh terhadap peningkatan ketebalan edible film sehingga kadar air akan turun. Semakin tinggi penambahan ekstrak juga akan menambah total padatan terlarut dalam suspensi edible film. Tingginya total padatan pada edible film secara langsung akan mempengaruhi kadar air ${ }^{14}$. Jadi, terlihat bahwa edible film terbaik terdapat pada sampel $\mathrm{ES}_{4}$ yaitu edible film dengan penambahan ekstrak $2 \mathrm{~g}$ dengan kadar air terendah yaitu sebesar 17,33\%.

Rendahnya kadar air edible film juga disebabkan karena ekstrak daun sirsak tersebut mengandung senyawa acetogenin lebih banyak. Senyawa ini bersifat non polar yang artinya sulit mengikat molekul air ${ }^{17}$. Selain mempengaruhi kadar air, sifat non polar dari senyawa acetogenin ini juga membuat proses gelatinisasi pada saat pembuatan edible film menjadi semakin lama seiring penambahan jumlah ekstrak daun sirsak yang semakin banyak.

Berbeda dengan sampel $\mathrm{ES}_{1}$ yang memiliki kadar air paling tinggi sebesar 20,33\%. Kadar air edible film yang tinggi akan mempengaruhi ketahanan film. Edible film yang bersifat biodegradable dengan kadar air yang tinggi akan mudah ditumbuhi oleh mikroba, karena adanya komponen nutrisi dalam film seperti karbohidrat dan protein. Sebaliknya Edible film yang mempunyai kadar air rendah akan lebih tahan terhadap kerusakan mikrobiologis sehingga umur simpan bahan lebih lama ${ }^{17}$.

Analisis antioksidan dilakukan menggunankan larutan DPPH. Metode peredaman radikal bebas DPPH didasarkan pada reduksi dari larutan metanol radikal bebas DPPH yang berwarna oleh penghambatan radikal bebas. Ketika larutan DPPH yang berwarna ungu bertemu dengan bahan pendonor elektron maka DPPH akan tereduksi, menyebabkan warna ungu akan memudar dan digantikan warna kuning yang berasal dari gugus pikril ${ }^{15}$. Hal ini terlihat dari perbedaan warna sampel yang diuji dengan metode DPPH pada Gambar 4.

Hasil uji menyatakan bahwa aktifitas antioksidan pada sampel $\mathrm{ES}_{1}$ yaitu edible film dengan penambahan ekstrak daun sirsak $0 \mathrm{~g}$ tergolong lemah terlihat dari nilai $\mathrm{IC}_{50}$ sebesar $177,471 \mathrm{mg} / \mathrm{mL}$. Sedangkan aktifitas antioksidan pada sampel $\mathrm{ES}_{2}, \mathrm{ES}_{3}$, dan $\mathrm{ES}_{4}$ yaitu edible film dengan penambahan ekstrak daun sirsak0,5 g, $1 \mathrm{~g}$, dan $2 \mathrm{~g}$ tergolong sangat kuat dilihat dari nilai $\mathrm{IC}_{50}$ yang semakin kecil dengan nilai berturut-turut
$5,3992 \mathrm{mg} / \mathrm{mL}, 2,4152 \mathrm{mg} / \mathrm{mL}$, dan $1,5875 \mathrm{mg} / \mathrm{mL}$. Adanya perbedaan kecerahan warna antara sampel $\mathrm{ES}_{2}$ dan $\mathrm{ES}_{3}$ karena pengaruh pigmen klorofil tidak serta merta membuat aktifitas antioksidan pada sampel $\mathrm{ES}_{2}$ lebih kuat dibandingkan sampel $\mathrm{ES}_{3}$.

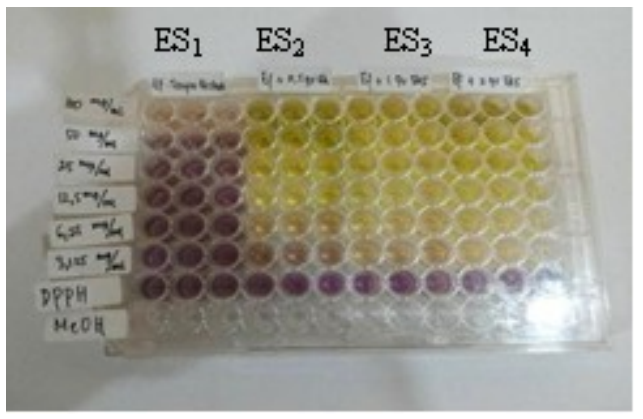

Gambar 4. Uji Antioksidan oleh DPPH

Semakin pekat warna kuning yang dihasilkan pada microplate reader maka semakin kuat aktifitas antioksidan yang dihasilkan. Hal ini terlihat dari nilai $\mathrm{IC}_{50}$ yang dapat dilihat pada Tabel 2.

Tabel 2. Hasil Pengukuran Uji Antioksidan terhadap Edible film.

\begin{tabular}{cc}
\hline Sampel & $\begin{array}{c}\text { Nilai IC50 } \\
(\mathbf{m g} / \mathbf{m L})\end{array}$ \\
\hline $\mathrm{ES}_{1}$ & 177,471 \\
$\mathrm{ES}_{2}$ & 5,3992 \\
$\mathrm{ES}_{3}$ & 2,4152 \\
$\mathrm{ES}_{4}$ & 1,5875 \\
\hline
\end{tabular}

Aktifitas antioksidan tertinggi terletak pada sampel $\mathrm{ES}_{4}$ yaitu edible film dengan penambahan ekstrak $2 \mathrm{~g}$ yang memiliki nilai $\mathrm{IC}_{50}$ sebesar 1,5875 $\mathrm{mg} / \mathrm{mL}$. Semakin banyak ekstrak yang ditambahkan maka aktifitas antioksidan edible film semakin kuat. Hal ini dipengaruhi adanya senyawa flavonoid yang terkandung dalam daun sirsak. Flavonoid dapat berperan sebagai antioksidan karena flavonoid bertindak sebagai free radical scavengers dengan melepaskan atom hidrogen dari gugus hidroksilnya. Atom hidrogen yang dilepaskan mampu berikatan dengan radikal bebas, hingga bermuatan netral. Flavonoid yang kehilangan atom hidrogen kemudian mengalami resonansi dari gugus hidroksil yang menyebabkan energi aktivitasnya berkurang dan tetap stabil. Radikal bebas yang sudah distabilkan akan berhenti melakukan reaksi berantai sehingga mencegah terjadinya kerusakan lipid, protein, atau DNA ${ }^{19}$.

Dari penelitian ini dapat dikatakan bahwa penambahan ekstrak daun sirsak mampu meningkatkan manfaaat lain edible film yang berfungsi sebagai pelindung makanan yang 
dikemas terhadap proses oksidasi dan menangkal radikal bebas yang masuk ke dalam tubuh.

\section{Kesimpulan}

Dari hasil penelitian dapat diambil kesimpulan bahwa : Karakteristik fisik edible film dilihat dari uji transmisi uap air telah memenuhi standar JIS 1975. Karakteristik kimia edible film yang meliputi uji kadar air, semua edible film dengan penambahan ekstrak daun sirsak telah memenuhi standar SNI. Sedangkan pada uji antioksidan nilai $\mathrm{IC}_{50}$ yang menunjukkan aktivitas antioksidan tertinggi pada edible film dengan penambahan ekstrak daun sirsak 2 g yaitu 1,5875 $\mathrm{mg} / \mathrm{mL}$.

\section{Referensi}

1. Ismanto dan U. B. Surono. 2016. Pengolahan Sampah Plastik Jenis PP, PET, dan PE Menjadi Bahan Bakar Minyak dan Karakteristiknya. Mekanika dan Sistem Termal (JMST). 1 (1), hlm. 33.

2. D. Huri dan F. C. Nisa. 2014. Pengaruh Konsentrasi Gliserol dan Ekstrak Ampas Kulit Apel terhadap Karakteristik Fisik dan Kimia Edible Film. Pangan dan Agroindustri. 2 (4), hlm. 29.

3. E. N. Sari, Marniza, dan Zulferiyenni. 2014.Pengaruh Konsentrasi Gliserol dan Tapioka terhadap Karakteristik Biodegradable Film Berbasis Ampas Rumpul Laut Eucheuma cottonii. Teknologi dan Industri Hasil Pertanian. 19 (3), hlm. 258.

4. D. Widyawati, dkk. 2013. Pembuatan Edible Film dari Tepung Jagung (Zea Mays L.) dan Kitosan. Prosiding Seminar Nasional Teknik Kimia "Kejuangan, hlm. 1.

5. F. Kusnandar. 2010. Kimia Pangan Komponen Makro,.Jakarta: Dian Rakyat, hlm. 106.

6. Departemen Agama RI. 2005. Mushaf AlQuran dan Terjemahannya. Jakarta: Al-Huda Kelompok Gema Insani, hlm. 268.

7. H. Wijayanti dan P. A. Handayani. 2015. Pembuatan Film Plastik Biodegradable dari Limbah Biji Durian (Durio Zibethinus Murr). Bahan Alam Terbarukan. 4 (1), hlm. 22.

8. L. Rahmidar, T. Sudiarti, dan W. Astuti. 2013. Preparasi dan Karakteristik Edible Film dari Poliblend Pati Sukun-Kitosan. Valensi. 3 (2), hlm. 107.

9. I. Yunianto, F. Wulaningrum, dan F. R. Yanti. 2014. Evaluasi Aktivitas Antioksidan Daun Sirsak (Annona muricara L.) pada Sistem Respirasi Mencit (Mus musculus) Terpapar Asap Anti Nyamuk Bakar sebagai Bahan Ajar
Biologi SMA kelas XI. Bioedukatika. 2 (2), hlm. 26.

10. H. Rivai, U. Kasypiah, dan Zulharmita.2012. Pembuatan dan Karakterisasi Ekstrak Kering Daun Jambu Biji (Psidium guajava, L.). Farmasi Higea. 4 (2), hlm. 147.

11. W. Hesmita dan P. A. Handayani. 2015. Pembuatan Film Plastik Biodegradable dari Limbah Biji Durian (Durio Zibethinus Murr). Bahan Alam Terbarukan. 4 (1), hlm.23

12. Aminah, dkk. 2014. Perbandingan Aktivitas Antioksidan Ekstrak Etanol Daun Sirsak (Annona Muricata L.) Berdasarkan Tempat Tumbuh dengan Metode Peredaman DPPH. Fitofarmaka Indonesia. 3 (1), hlm. 147.

13. A. Listyrini, M. I. Rizki, dan W. Pudjiastuti. 2013. Pengaruh Laju Transmisi Uap Air Polymer Blend Polibutilen Suksinat (Pbs) dan Linear Low Density Polyethylene (Lldpe) terhadap Umur Simpan Sup Krim Instan Rasi, Kimia Kemasan. 35 (1), hlm. 3.

14. D. A. Kusumawati dan W. D. Rukmiputri. 2013. Karakteristik Fisik dan Kimia Edible Film Pati Jagung yang Diinkorporasi dengan Perasan Temu Hitam. Pangan dan Agroindustri. 1 (1), hlm. 96.

15. Aryani, T. W. Sulistyaningrum, dan Norhayani. 2016. Pengaruh Penambahan Rumput Laut (Eucheuma cottonii) pada Pengolahan Fishstick Ikan Toman (Channa micropeltes). Ilmu Hewan Tropika. 5 (2), hlm. 59.

16. M. F. Arifin. Formulasi Edible film Ekstrak Daun Sirih (Piper betle L.) Sebagai Antihalitosis. Jakarta : Kongres Ilmiah ISFI XVII, 2009, hlm. 10.

17. Nurhayani, Siswarni, dan S. D. Sinaga. 2016. Ekstraksi Acetogenin dari Daun dan Biji Sirsak (Annona muricata L) dengan Pelarut Aseton. Teknik Kimia USU. 5 (2), hlm. 2. 